\title{
Veterans' case comes to court
}

\section{Washington}

THE complex saga of Agent Orange, 11 million gallons of which were sprayed on Vietnam between 1962 and 1971, will finally come to trial before a federal court in Brooklyn, New York, on 7 May. A jury will have to decide whether the chronic health problems of nine plaintiffs, including five veterans and three children born with catastrophic birth defects, were caused by exposure to dioxin contaminant tetrachlorodibenzodioxin (TCDD) found in the herbicide. A huge amount of money is at stake; the plaintiffs represent the entire class of veterans and families who attribute medical problems to exposure to Agent Orange. Damages awarded against the companies concerned could amount to thousands of millions of dollars.

Although the class action is directed principally against seven manufacturers of Agent Orange, the federal government is expected to be in court too - very much against its will. The manufacturers, claiming that the federal government knew about the possible health effects of the defoliant when it used it, have filed thirdparty complaints that could force the government to share in any liability. The courts have so far rejected the government's claim that it cannot be sued for injuries received during military service.

The question of who knew what about Agent Orange, and when, will be a central issue in the trial. One of the allegations made against the manufacturers is that one of them, the Dow Chemical Company, was worried about the toxicity of dioxin as early as 1965 , but tried to hide its concern from the federal government. Dow vigorously denies the charge. It says its worries in 1965 concerned the exposure of its employees to large concentrations of TCDD during manufacture, not use of the finished product which contained vastly lower concentrations. It also maintains that the Department of Defense knew at least as much as the manufacturers about the components of Agent Orange and the toxicity of TCDD.

But Dow and its co-defendants intend to base their defence on scientific arguments. They maintain that not enough research has yet been done to conclude whether the health of Vietnam veterans and their families differs significantly from that of the rest of the population. The evidence that is available, they argue, suggests that Agent Orange could not have caused the health problems ascribed to it.

Information about the effect of TCDD on humans is indeed sparse, although Congress has occasionally rapped the American Medical Association over the knuckles for saying so. Most of the data available have come from studies of industrial accidents, where victims are typically subjected to high exposures for short periods, not to low exposures over a long period as in the case of troops in Vietnam. Even so, the only TCDD-related disorder about which there is no argument is chloracne, the skin disease.

Preliminary studies of the impact of Agent Orange have so far failed to establish a clear link between the herbicide and the many disorders - including birth defects, lymphoma, neuromuscular weakness and liver enlargement - for which it has been blamed by veterans. The scientific evidence has been further muddied by the findings of the Air Force's own epidemiological study of the personnel involved in the "Ranch Hand" operation, as the herbicide-spraying operation was called. The Air Force reported in March that there was little evidence that the Ranch Handers had suffered as a result of contact with Agent Orange. None had soft-tissue sarcomas or chloracne, although the incidence of certain birth defects, skin cancer and liver disorders was high.

Like many other studies of Agent Orange, the Ranch Hand results have been hailed as a victory by both sides in the dispute. The Dow Chemical Company points out that the skin cancers could have been caused by exposure to sunlight; the veterans' lawyers said the study showed that science was beginning to "catch up" with what the veterans already knew - that Agent Orange damaged their health.

The Ranch Hand study, however, is only one of more than 60 federal studies of the effect of dioxin being conducted at a cost of some $\$ 100$ million a year. Because the number of Ranch Hand personnel was small, the study was not expected to be sensitive to rare illnesses, a point made forcefully by a National Academy of Sciences review of the Ranch Hand protocol in 1980. Meanwhile, a major research programme, including a study of identical twins of whom one brother served in Vietnam, is under way within the Veterans Administration.

At congressional insistence, however, the Veterans Administration has had to transfer responsibility for a major epidemiological study of veterans to the Centers for Disease Control (CDC) in Atlanta. The Veterans Administration is distrusted by veterans and has been accused repeatedly of reacting slowly and insensitively to veterans' anxieties about their health. The $\$ 70$ million epidemiological study will be the biggest ever conducted by CDC. Some 30,000 veterans will receive a detailed health interview and another 10,000 will be given extensive twoor three-day physical examinations in what CDC hope will become the definitive analysis of the Agent Orange question. But the results will not start to emerge for at least seven years, too late to help the Brooklyn jurors in May.

Peter David
Chinese nuclear industry

\section{Advance on broad front}

Discussic Ns on a possible $\$ 20,000$ million deal in nuclear technology were a major feature of President Reagan's visit to China last month. Coincidentally, the President's visit came shortly after the second national congress of the Chinese Nuclear Society, which reviewed the current state of Chinese nuclear technology and explored ways and means of "uniting and organizing" large numbers of scientists to meet the challenge of the nuclear age.

Addressing the inaugural session of the congress, Defence Minister Zhang Ai-Ping noted that although China has built a "fairly comprehensive" nuclear expertise over the past 20 years, and has started construction work on its first nuclear power station, at Taishan, the application of nuclear technology to the economy has been neglected. Satisfying the needs of "economic construction and improving people's standard of living"' must, he said, be a priority for the nuclear industry, although it must also "ensure the satisfaction of military needs".

In fact, considerable progress has already been made on the applications of nuclear technology. More than 1,700 nuclear radiation instruments are now used in the textile, printing, paper-making, plastics and petrochemical industries. Between four and five thousand oil wells have been logged by radioactive methods, radiation sand-gauges have been installed in 12 hydrometric stations along the Yellow River to monitor sand content of the water and tracer techniques used for safety surveys of reservoirs.

Future plans include two more nuclear power stations (one in Zhejiang Province and one in the Shenzhen Special Economic Zone) and two 450-MW combined heat and power units for the Jinshang petrochemical works in Shanghai. Feasibility studies are in progress for urban central heating systems. According to Jiang Xinxiong, the Minister of the Nuclear Industry, China plans to be self-sufficient in nuclear fuel by the end of the century, while experimental work on fast breeder reactors and controlled thermonuclear fusion is "making progress".

The main problem, according to Defence Minister Zhang, is, however, safety, and, at the same time, popularization of knowledge about the peaceful use of nuclear energy in order to dispel "misgivings and apprehensions". The Chinese nuclear industry, Zhang said, is quite capable of handling fuel reprocessing, but should go on improving facilities and techniques in this field. Some experts believe that it could also undertake reprocessing on a commercial basis for other countries. 